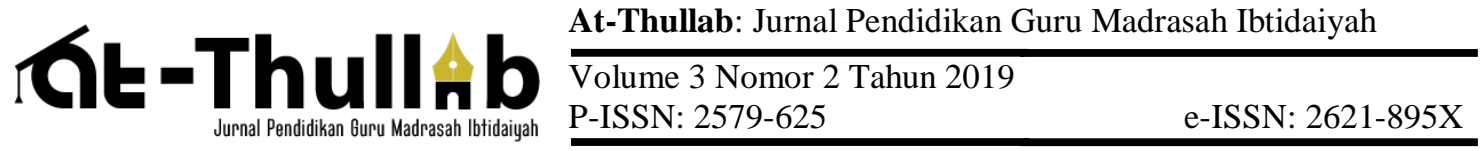

\section{IMPLEMENTASI KURIKULUM 2013 DALAM PEMBELAJARAN IPA; STUDI KASUS DI MI ROUDLOTUL ULUM SURABAYA}

\author{
Syamsudin $^{1}$, Luluk Safitri ${ }^{2}$ dan Musdalifah ${ }^{3}$ \\ ${ }^{1,2,3}$ STAI Al-Fithrah Surabaya \\ e-mail: ${ }^{1}$ syamsudinalfithrah@ @mail.com, ${ }^{2}$ luluksafitrielhakie@gmail.com, \\ ${ }^{3}$ muzdalifah.2806@ gmail.com
}

\begin{abstract}
This research aims to know how the science learning process in the implementation of the 2013 curriculum at MI Roudlotul Ulum Surabaya. This research focuses on the process of planning, implementing, and evaluating outcomes and obstacles faced by the teacher in implementing science learning of the 2013 curriculum. The method used in this research is qualitative descriptive. The data analysis in this study is reducting data, presenting data, and drawing conclusions. Based on the data analysis it can be concluded that the science learning in implementing of 2013 curriculum in MI Roudlotul Ulum Surabaya uses the scientific method. Moreover, the assessment uses authentic assessment that is consistent with the 2013 curriculum which includes aspects of attitude, aspect of knowledge, and aspect of skills. The obstacle faced by teachers in the learning process is students have a different absorption and understanding of a teaching material. It can be overcome by guiding by the teacher when guiding work in a group.
\end{abstract}

Keywords: Implementation of 2013 Curriculum, Science Learning, 2013 Curriculum Imlpementation in Science Learning

\section{A. Pendahuluan}

Kurikulum di Indonesia dalam sejarahnya telah mengalami perubahan berkalikali, hal ini dilakukan untuk memperbaiki kualitas pendidikan yang ada di Indonesia. Perubahan kurikulum mulai dari Kurikulum Tingkat Satuan Pendidikan menjadi Kurikulum 2013, perlu disikapi dan dipahami oleh berbagai pihak dalam dunia pendidikan karena keberadaan kurikulum menjadi jantungnya dunia pendidikan yang menentukan kualitas pendidikan di Indonesia. Kurikulum 2013 direncanakan diterapkan di sekolah-sekolah yang ada di Indonesia, mulai dari tingkat Sekolah Dasar (SD)/ Madrasah Ibtidaiyah (MI), tingkat Sekolah Menengah Pertama (SMP)/ Madrasah Tsanawiyah dan Sekolah Menengah Atas (SMA)/Madrasah Aliyah. Pada mulanya hanya sebagian kelas dari berbagai tingkat satuan pendidikan yang dijadikan uji coba. Selanjutnya tepat pada tahun ajaran baru 2014-2015 kurikulum 2013 diterapkan secara serentak diseluruh jenjang pendidikan mulai dari tingkat dasar sampai tingkat menengah. Implementasi kurikulum 2013 pada mulanya mungkin terkesan sedikit dipaksakan karena tidak seluruh sekolah siap untuk mengimplementasikan kurikulum 
yang baru ini. Pemahaman guru masih belum merata yang disebabkan pelatihan untuk implementasi kurikulum 2013 hanya dilakukan pada beberapa guru perwakilan dari setiap sekolah yang mengikutinya.

Perubahan kurikulum harus ditunjang oleh guru yang benar-benar menguasai substansi dari kurikulum yang berkaitan dengan kompetensi profesional dan pedagogic (Mulyasa, 2015). Kurikulum 2013 dalam memahaminya tentu membutuhkan waktu yang tidak sedikit, terlebih dengan adanya tema-tema pada penerapannya dan istilahistilah baru yang muncul seperti 1) Kriteria Ketuntasan Minimun (KKM) menjadi Ketuntasan Belajar Minimal (KBM); 2) Standar Kompetensi (SK) menjadi Kompetensi Inti (KI); 3) Ulangan Harian (UH) menjadi Penilaian Harian (PH); 4) Ulangan Tengah Semester (UTS) menjadi Penilaian Tengah Semester (PTS); 5) Ulangan Akhir Semester (UAS) menjadi Penilaian Akhir Semerter (PAS); 6) Ulangan Kenaikan Kelas (UKK) menjadi Penilaian Akhir Tahun (PAT) dan lain sebagainya. Hal ini sesuai dengan penelitian yang dilakukan Ariany, dkk. (2017) bahwa masih terdapat kekurangan dan kelemahan dalam implementasi Kurikulum 2013 yang terlihat dari adanya kesenjangan pada keterpenuhan Standar Nasional Pendidikan terutama pada standar proses dan standar penilaian yang belum menerapkan penilaian autentik dalam proses pembelajaran (Ariany, 2017).

Kurikulum 2013 membawa perubahan mendasar dalam proses pembelajaran. Oleh karena itu, guru harus menyiapkan diri untuk meningkatkan kompetensi agar dapat melaksanakan amanat kurikulum dengan baik. Salah satu alternatif yang dapat dilakukan guru untuk meningkatkan kemampuan penalaran ilmiah siswa adalah dengan memberikan pertanyaan-pertanyaan yang dapat memacu proses berpikir tingkat tinggi. Sehingga guru dalam pembelajaran IPA harus mengkondisikan pembelajaran yang dapat memfasilitasi hal tersebut (Wulandari, 2018). MI Roudlotul Ulum Surabaya memiliki sarana dan prasarana yang sangat memadai ditambah dengan antusiasme guru dalam belajar sangat tinggi memiliki ketertarikan tersendiri untuk dikaji proses penerapan Kurikulum 2013 terutama pada pembelajaran IPA.

Artikel ini membahas tentang bagaimana guru menyiapkan pembelajaran yang meliputi perencanaan mulai dari mengkaji dan mencermati KI dan KD pada silabus serta buku guru dan mencermati sumber-sumber dari buku lain sebelum nantinya menyusun RPP dan melaksanakan kegiatan pembelajaran yang meliputi pendahuluan, inti dan penutup, serta penilaian pembelajaran baik penilaian aspek pengetahuan, aspek sikap sampai aspek keterampilan. Hal ini diharapkan akan menjadi bahan pembelajaran bagi guru yang akan mengimplemetasikan Kurikulum 2013 dan bahan kajian bagi peneliti terutama pada materi, tema ataupun pembelajaran yang lain.

\section{B. Metode}


Penelitian ini menggunakan metode penelitian kualitatif deskriptif yang dalam penyajian datanya berupa kata-kata yang dapat ditarik sebuah kesimpulan sebagai hasil dari penelitian. Metode penelitian kualitatif deskriptif merupakan metode penelitian yang digunakan oleh peneliti untuk menemukan pengetahuan atau teori terhadap penelitian pada suatu waktu tertentu (Mukhtar, 2013). Melalui metode penelitian ini peneliti mencoba mengungkapkan implementasi kurikulum 2013 pada pembelajaran IPA di MI Roudlotul Ulum, Surabaya.

Teknik analisis data pada penelitian ini menggunakan model Miles dan Hubermen yang dalam aktivitas penelitiannya meliputi reduksi data, penyajian data dan penarikan kesimpulan. Sumber data primer pada penelitian ini adalah hasil wawancara dari guru kelas di MI Roudlotul Ulum Surabaya. Wawancara merupakan salah satu teknik pengumpulan data yang digunakan untuk menghimpun bahan-bahan keterangan yang dilaksanakan dengan melakukan tanya jawab lisan secara sepihak, bertatap muka dan memiliki tujuan tertentu (Nazir, 2014). Jenis wawancara yang digunakan oleh peneliti adalah wawancara terstruktur. Wawancara menggunakan pedoman wawancara atau kisi-kisi pertanyaan agar dalam wawancara data yang ingin digali peneliti tidak ada yang terlewat. Data dikumpulkan untuk kemudian dianalisis dengan teknik reduksi data, penyajian data, dan penarikan kesimpulan. Sedangkan sumber data sekunder pada penelitian ini adalah dokumen-dokumen perangkat pembelajaran yang meliputi Rencana Pelaksanaan Pembelajaran (RPP), silabus, buku guru dan buku siswa dan lain sebagainya serta hasil observasi terhadap sumber belajar siswa yang lain seperti media pembelajaran yang ada disekolah untuk pembelajaran IPA dan lingkungan sekolah yang mendukung. Observasi sendiri merupakan suatu teknik atau cara pengumpulan data dengan mengadakan pengamatan terhadap suatu kegiatan yang sedang berlangsung (Sukmadinata, 2013).

\section{Hasil dan Pembahasan}

1. Pembelajaran IPA dalam Kurikulum 2013

Kurikulum 2013 merupakan pengembangan dari kurikulum sebelumnya yakni Kurikulum Tingkat Satuan Pendidikan (KTSP). Dalam kurikulum 2013 pendekatan yang digunakan adalah pendekatan saintifik dengan model pembelajaran tematik terpadu. Keunggulan pada kurikulum ini adalah telah memenuhi tiga komponen utama pendidikan yang yakni, pengetahuan, keterampilan dan sikap yang menekankan pada pendidikan karakter.

Menurut Peraturan Menteri Pendidikan dan Kebudayaan Republik Indonesia No. 57 Tahun 2014 tentang kurikulum 2013 Sekolah Dasar/Madrasah Ibtidaiyah, kurikulum 2013 bertujuan untuk mempersiapkan manusia Indonesia agar memiliki kemampuan hidup sebagai pribadi dan warga negara yang beriman, produktif, kreatif, inovatif dan 
afektif serta mampu berkontribusi pada kehipan bermasyarakat, berbangsa, bernegara dan peradaban dunia (Kebudayaan, 2016). Kurikulum 2013 dalam penerapannya memiliki karakteristik tertentu pada pembelajarannya yaitu 1) menggunakan pendekatan saintifik; 2) menggunakan ilmu pengetahuan sebagai penggerak pembelajaran untuk semua mata pelajaran; 3) menuntun peserta didik untuk mencari tahu bukan diberi tahu ; 4) menekankan kemapuan berbahasa sebagai alat komunikasi, pembawa pengetahuan dan berfikir logis, sistematis dan kreatif. (Khusniati dan Pamelasari, 2014). Menurut Trianto (2007) Ilmu Pengetahuan Alam (IPA) merupakan pengetahuan ilmiah yang sistematis, teratur, universal dan diperoleh melalui pengumpulan data dengan eksperimen, observasi dan deduksi untuk menghasilkan suatu penjelasan terkait suatu gejala yang dapat dipercaya yang pokok bahasannya adalah alam dan seisinya. IPA juga merupakan kumpulan teori yang sistematis pada gejala-gejala alam dan dikembangkan melalui metode ilmiah dan menuntut sikap ilmiah (Syamsudin, 2019).

IPA sebagai integratif science secara umum mempelajari fenomena-fenomena alam yang tidak mungkin ada tanpa campur tangan Tuhan Yang Maha Kuasa. Hal inilah yang menjadikan IPA sebagai ilmu yang dapat diintegrasikan pada pendidikan karakter peserta didik. Nilai-nilai karakter diharapkan mampu memberikan dampak positif pada perilaku peserta didik, sehingga nantinya mampu membentuk genenrasi yang beriman dan bertakwa kepada Tuhan Yang Maha Esa, berakhlak mulia, dan berkepribadian luhur, berilmu, cakap, kritis, kreatif, inovatif, sehat, mandiri, percaya diri, toleran, demokratis dan bertanggung jawab (Syamsudin, 2019). Pembelajaran IPA juga dapat membiasakan peserta didik secara individual maupun kelompok dapat dengan aktif mengekplorasi, mengelaborasi, mengkonfirmasi dan mengkomunikasikan hasilnya (Ariany, 2017). Didukung hasil wawancara yang kami lakukan pada guru kelas di MI Roudlotul Ulum Surabaya menyatakan bahwa IPA merupakan ilmu pasti dan contohnya tersedia di lingkungan sekitar kita. Berdasar beberapa pendapat tersebut dapat disimpulkan bahwa IPA merupakan pengetahuan ilmiah yang pokok pembahasannya pada gejala alam, dan tergolong dalam pengetahuan ilmiah yang sistematis, teratur, universal dan diperoleh melalui pengumpulan data dengan metode ilmiah.

2. Implementasi Kurikulum 2013 dalam Pembelajaran IPA

Kurikulum 2013 dalam implementasinya pada pembelajaran IPA menuntut peserta didik untuk lebih aktif dalam menemukan hal-hal baru dan menyimpulkan permasalahan yang ada di dalamnya. Guru dalam kegiatan pembelajaran tersebut diharapkan dapat menggunakan strategi, model, pendekatan serta bahan yang cocok dalam kegiatan pembelajarannya (Bungkang, 2016).

a. Perencanaan Pembelajaran 
Hal pertama yang dilakukan oleh seorang guru sebelum melaksanakan proses pembelajaran adalah menyusun perencanaan pembelajaran. Perencanaan pembelajaran merupakan kegiatan dalam menentukan tindakan apa yang akan diambil dalam suatu kegiatan belajar mengajar yang diwujudkan dengan melakukan koordinasi terhadap komponen-komponen pembelajaran, sehingga tujuan, isi materi, metode dan teknik pembelajaran, media pembelajaran, serta cara dalam mengevaluasi suatu kegiatan pembelajaran agar menjadi jelas dan sistematis (Sudjana, 2014).

Keseluruhan dari perencanaan tersebut tertuang dalam perangkat pembelajaran guru. Perencanaan tersebut lebih sering dikenal dengan sebutan Rencana Pelaksanaan Pembelajaran (RPP). Dalam penyusunan perencanaan pembelajaran maka guru harus memperhatikan beberapa beberapa hal yaitu 1) menentukan apa yang akan dilakukan, kapan dan bagaimana cara melakukannya; 2) menentukan sasaran atau target yang ingin dicapai; 3) mengembangkan alternatif-alternatif lain; 4) mengumpulkan dan menganalisis informasi; 5) mempersiapkan dan mengkomunikasikan rencana-rencana dan keputusan yang akan diambil (Zain, 2014).

Berdasarkan hasil penelitian ini, guru kelas di MI Roudlotul Ulum Surabaya menyusun RPP pada awal tahun dengan berpedoman pada KI dan KD serta silabus yang disusun oleh pemerintah. Tahapan-tahapan yang dilakukan guru dalam menyusun perencanaan pembelajaran meliputi mengkaji silabus, mengakaji buku guru dan buku siswa, mengkaji sumber-sumber lain (buku pegangan guru) yang kemudian dilanjutkan dengan menyusun RPP. Berdasar hasil wawancara yang kami lakukan menunjukkan bahwa pada proses perencananaan pembelajaran tersebut guru mengkaji dan mencermati KI dan KD pada silabus serta buku guru dan mencermati sumber-sumber dari buku lain (buku pegangan guru) sebelum nantinya menyusun RPP dan melaksanakan kegiatan pembelajaran.

b. Pelaksanaan Pembelajaran

Pada tahap pelaksanaan pembelajaran sedikit banyak guru tentu berpedoman pada RPP yang telah disusunnya. Berdasarkan hasil observasi dan wawancara yang kami lakukan diketahui bahwa guru kelas telah melaksanakan pembelajaran sesuai dengan RPP yang disusun. Keberhasilan dalam suatu kegiatan pembelajaran ini tidak terlepas dari kreatifitas guru, dukungan dari sekolah dan lingkungan sekitar sekolah. Berdasarkan kegiatan observasi yang kami lakukan terkait implementasi kurikulum 2013 pada pembelajaran IPA kelas di MI Roudlotul Ulum Surabaya, terdapat tiga kegiatan utama yang dilakukan oleh guru dalam pelaksanaan pembelajarannya adalah: 
1) Pendahuluan

Berdasarkan hasil observasi, pada kegiatan pendahuluan guru mengkondisikan siswa untuk duduk rapi dan berdoa. Selanjutnya guru menyapa siswa, memberikan motivasi kepada siswa, memberikan apersepsi, menyampaikan materi dan tujuan yang akan dicapai.

2) Inti

Berdasarkan hasil observasi dan wawancara, pada kegiatan inti guru menunjukkan sebuah tanaman yang ada didepan kelas, sebagai contoh dari adanya proses ekosistem dilingkungan sekitar. Pada pembelajaran ini guru menggunakan pendekatan saintifik yaitu pendekatan yang menjadi karakteristik dari kurikulum 2013. Pada pelaksanaan pembelajaran kali ini guru menghadirkan langsung contoh ekosistem dari alam. Hal ini sesuai dengan pendapat Ridwan dan Bungkang (2017) yang menyatakan bahwa guru dalam kegiatan pembelajaran diharapkan dapat menggunakan strategi, model, pendekatan serta bahan yang cocok dalam kegiatan pembelajarannya. Media tanaman yang digunakan bertujuan untuk mempermudah penyampaian materi terkait ekosistem dalam pembelajaran tersebut. Sehingga siswa lebih mudah dalam memahami materi yang diajarkan dan difasilitasi pembelajarnnya oleh guru.

3) Penutup

Berdasarkan hasil observasi, pada kegiatan penutup guru membantu siswa dalam menyimpulkan materi hari ini, yakni terkait materi ekosistem, dilanjutkan dengan melakukan refleksi berupa pengajuan pertanyaan kepada siswa terkait materi ekosistem, pemberian umpan balik dengan memberikan penguatan materi pada siswa terkait materi ekosistem, melakukan penilaian terhadap siswa dan merencanakan kegiatan tindak lanjut serta menyampaikan rencana pembelajaran pada pertemuan berikutnya.

Konsentrasi belajar siswa memiliki pengaruh yang besar terhadap siswa. Menurut Prayitno dan Erman Amti konsentrasi mampu membuat seseorang menguasai apa yang dipelajarinya, karena dengan konsentrasi seluruh perhatian akan tertuju pada apa yang sedang menjadi perhatiannya (Amti, 2013). Diperlukan pemberian motivasi pada siswa dalam upaya meningkatkan konsentrasi. Hal ini dapat diwujudkan dalam berbagai bentuk antara lain dengn pujian, belajar diluar ruangan, memberikan peringatan pada siswa dengan kata duduk dan bersiap dalam hitungan 1-5 dan pemberian nasihat. Oleh karenanya dalam pelaksanaan pembelajaran guru haruslah memiliki kesiapan yang matang, termasuk dalam hal memotivasi siswa. Konsentrasi siswa pada umumnya dalam suatu mata pelajaran 
hanya dapat bertahan beberapa saat saja. Pemberian motivasi dan ice breaking pada pelaksanaan pembelajaran menjadi obat untuk mengobati kejenuhan siswa.

c. Penilaian Pembelajaran

Tahap ketiga dalam suatu pembelajaran adalah kegiatan penilaian. Menurut Peraturan Menteri Pendidikan dan Kebudayaan Nomor 23 tahun 2016 tentang standar penilaian, menyatakan bahwa penialaian merupakan proses pengumpulan data dan pengelolaan informasi untuk mengukur pencapaian hasil belajar peserta didik (Kebudayaan, 2016).

Berdasarkan hasil wawancara pada guru kelas tekait implementasi kurikulum 2013 pada pembelajaran IPA di MI Roudlotul Ulum Surabaya guru menggunakan model penilaian autentik. Berdasar hasil wawancara tersebut guru melakukan penilaian terhadap sikap, pengetahuan dan keterampilan siswa. Hal ini sesuai dengan penilaian autentik pada kurikulum 2013 yang menekankan pada aspek sikap, pengetahuan dan keterampilan siswa.

Berikut ini adalah hal yang dilakukan oleh guru pada kegiatan penilaian pembelajaran, terkait penilaian sikap, pengetahuan dan keterampilan, berikut penjelasannya:

1) Penilaian dari aspek sikap

Berdasarkan hasil observasi dan wawancara pada aspek penilaian sikap, guru melakukan penilaian sikap terhadap sikap siswa dalam hal taat beribadah, bersyukur atas rahmat dan kasih sayang yang diberikan Allah SWT kepada hambanya, sikap siswa pada saat berdoa, dan sikap toleransi siswa terhadap keragaman yang ada, hal ini dimuat dalam lembar penilaian sikap KI-1. Sedangkan pada lembar penilaian sikap KI-2, sikap yang dinilai oleh guru adalah sikap tanggung jawab, disiplin, kerjasama dan percaya diri. Dalam aspek penilaian sikap ini guru melakukannya dengan mengamati seacara langsung perilaku siswa. Bahkan beliau menyatakan bahwa penanaman nilai-nilai spiritual sangat ditekankan pada kegiatan pembelajarannya. Guru memiliki kegiatan tadarrus bersama untuk menanamkan nilai-nilai agama pada diri siswa. Proses penilaiannya pun terbagi menjadi dua yakni penilaian diri dan penilaian yang berdasarkan pengamatan guru. Penilaian diri ini bertujuan untuk melatih siswa untuk dapat bertanggungjawab dan jujur dengan apa yang sudah dilakukan. Sedangkan penilaian berdasarkan pengamatan guru ini untuk mengkonfirmasi hasil penilaian diri siswa dan mengecek tanggungjawab dan kejujuran siswa.

2) Penilaian dari aspek pengetahuan

Penilaian pada aspek pengetahuan guru menggunakan instrumen tes tulis, tes lisan dan pemberian tugas. Tes tulis yang digunakan berupa soal isian yang diberikan guru dan soal isian singkat yang ada di buku siswa. Sedangkan untuk 
penilaian tes lisan dilakukan oleh guru pada kegiatan apersepsi di awal pembelajaran dan kegaiatan refleksi di akhir pembelajaran. Hal ini sesuai dengan pendapat (Wulandari, 2018) bahwa Salah satu alternatif yang dapat dilakukan guru untuk meningkatkan kemampuan penalaran ilmiah siswa adalah dengan memberikan pertanyaan-pertanyaan yang dapat memacu proses berpikir tingkat tinggi. Sehingga guru dalam pembelajaran IPA harus mengkondisikan pembelajaran yang dapat memfasilitasi hal tersebut. Pada kegiatan pemberian tugas guru meminta siswa untuk membuat kliping terkait materi ekosistem. Tugas tersebut selain untuk mengembangkan pengetahuan siswa juga sebagai bentuk untuk melatih sikap tanggungjawab siswa. Sehingga pemberian tugas pada siswa dapat memberikan berbagai manfaat sekaligus.

3) Penilaian dari aspek keterampilan

Pada aspek keterampilan guru menggunakan penilaian unjuk kerja. Aspek yang dinilai oleh guru pada keterampilan ini, adalah keterampilan siswa dalam menyusun dan mendemonstrasikan laporan hasil pengamatannya terkait materi ekosistem pada tema 6 kelas V. Kemampuan keterampilan siswa dalam membuat kliping termasuk bagian dari aspek penilaian keteerampilan siswa, mulai dari sumber yang dikumpulkan, segi peletakan dan kerapian hasil. Selanjutnya menurut hasil wawancara, pada implementasi kurikulum 2013 pada pembelajaran IPA guru juga melakukan penilaian pada hasil kerja proyek siswa, seperti membuat kerajinan dari bahan flanel.

\section{Hambatan dalam Implementasi Kurikulum 2013 Pada Pembelajaran IPA}

Berdasar hasil wawancara dan observasi yang kami lakukan didapatkan bahwa hambatan yang dihadapi oleh guru pada implementasi pembelajaran kurikulum 2013 pada pembelajaran IPA di MI Roudlotul Ulum Surabaya adalah kondisi siswa yang memiliki daya serap terhadap materi pelajaran yang berbeda-beda. Hal ini sesuai dengan penelitian Arif dan Sulistianah bahwa salah satu hambatan dari lima hambatan yang ditemukan dalam implementasi Kurikulum 2013 adalah masalah dari siswa (Sulistianah, 2019). Kondisi siswa di kelas V B terdiri dari 37 siswa sebagai sampel menunjukkan tingkat daya serap siswa terhadap suatu materi pelajaran sangatlah bervariasi. Jika dibagi maka tingkat daya serap dan pemahaman siswa terhadap suatu materi di kelas $\mathrm{V}$ B terbagi kedalam tiga tingkatan, yakni tingkat rendah, tingkat sedang dan tingkat tinggi. Pada siswa yang memiliki tingkat daya serap dan pemahaman rendah, untuk meningkatkan hasil belajarnya guru selalu memberikan bimbingan dan motivasi kepada siswa, hal ini dilakukan agar siswa tidak merasa minder dengan kemampuan yang dimilikinya. Bimbingan yang diberikan pada siswa yang berada pada tingkat daya serap dan pemahaman yang rendah ini guru juga memberikan soal-soal yang berbeda dengan teman-temannya yang lain. Hal ini dilakukan agar siswa mampu meningkatkan motivasi 
belajara pada diri sendiri dan mampu meningkatkan hasil belajarnya. Guru juga melakukan bimbingan dan perhatian khusus kepada siswa dengan tingkat daya serap dan pemahaman rendah ketika pembeimbingan kelompok saat proses pembelajaran pada fase diskusi kelompok.

Selanjutnya pada siswa yang memiliki tingkat daya serap dan pemahaman yang sedang, guru selalu memberikan bimbingan yang sama dengan siswa tingkat tinggi. Menurut beliau hal tersebut dilakukan karena sesungguhnya siswa tersebut mampu, akan tetapi hanya membutuhkan tambahan sedikit waktu dalam menyelesaikan tugas yang diberikan oleh guru. Sedangkan untuk siswa yang memiliki tingkat daya serap dan pemahaman tinggi, guru terus memberikan semangat dan membantu siswa tersebut untuk melanjutkan ke materi selanjutnya, dan pastinya tetap dalam pengawasan guru. Serta diarahkan untuk dapat membantu siswa yang memiliki tingkat daya serap dan pemahaman rendah serta siswa yang memiliki tingkat daya serap dan pemahaman sedang. Hal ini dilakukan untuk menumbuhkan rasa percaya diri pada siswa serta mengambangkan sikap sosial siswa yaitu tanggungjawab dan kerjasama.

\section{Simpulan}

Berdasarkan pemaparan tersebut dapat disimpulkan bahwa dalam implementasi Kurikulum 2013 pada pembelajaran IPA di MI Roudlotul Ulum Surabaya guru telah melakukan perencanaan yang sistematis. Kegiatan perencanaan tersebut dimulai dari mengkaji silabus, mengkaji buku guru dan bukku siswa, mengkaji sumber-sumber belajar lain dan dilanjutkan dengan penyusunan Rencana Pelaksanaan Pembelajaran. Guru dalam pelaksanaan pembelajaran menggunakan pendekatan saintifik, sedangkan dalam penilaiannya sesuai dengan penilaian dalam kurikulum 2013 yakni penilaian autentik yang meliputi aspek sikap, aspek pengetahuan dan aspek keterampilan. Adapun hambatan yang dihadapi oleh guru dalam pelaksanaan pembelajaran berasal dari kondisi siswa sendiri, yang mana tingkat daya serap dan pemahaman siswa terhadap suatu materi beragam. Hal ini dapat diatasi dengan pemberian bimbingan oleh guru ketika membimbing kerja kelompok. Artikel ini hanya membahas implementasi kurikulum 2013 pada pembelajaran IPA di MI Roudlotul Ulum Surabaya. Perlu penelitian lebih lanjut tentang implementasi Kurikulum 2013 pada pembelajaran yang lain dengan berbagai metode dan model pembelajaran, sehingga dapat memberikan sumbangsih untuk peningkatan kualitas pembelajaran yang lebih baik. 


\section{Daftar Rujukan}

Amti, P. dan E. (2013). Dasar-Dasar Bimbingan Konseling. Jakarta: Depdikbud.

Ariany, Y. (2017). Problematika Pelaksanaan Kurikulum 2013 Dalam Pembelajaran IPA Kelas VII SMP Negeri di Kecamatan Lima Kaum Tahun 2017-2018. Journal Biosains, 1(2).

Bungkang, L. R. dan Y. (2016). Implementasi Kurikulum 2013 Pada Pembelajaran IPA di SMP Se-Kota Jayapura Tahun Ajaran 2016-2017. Jurnal Ilmu Pendidikan Indonesia, 4(3). Retrieved from https://ejournal.uncen.ac.id/index.php/JIPI/article/view/379

Kebudayaan, K. P. dan. Permendikbud RI No. 23 Tahun 2016 tentang Standar Penilaian Pendidikan (2016). Indonesia.

Mukhtar. (2013). Metode Praktis Penelitian Deskriptif Kualitatif. Jakarta: Referensi.

Mulyasa, E. (2015). Pengembangan Implementasi Kurikulum 2013. Bandung: PT Remaja Rosdakarya.

Nazir, M. (2014). Metode Penelitian. Jakarta: Ghalia Indonesia.

Sudjana, N. (2014). Penilaian Hasil Proses Belajar Mengajar (VI). Bandung: PT Remaja Rosdakarya.

Sukmadinata, N. S. (2013). Metode Penelitian Pendidikan. Bandung: PT . Remaja Rosda Karya.

Sulistianah, M. A. (2019). Problems in 2013 Curriculum Implementation for Classroom Teachers in MadrasahIbtidaiyah. Al Ibtida: Jurnal Pendidikan Guru MI, 6(1). https://doi.org/http://dx.doi.org/ 10.24235/al.ibtida.snj.v6i1.3916

Syamsudin. (2019). Mengembangkan Keterampilan Sosial Siswa MI/SD Dalam Pembelajaran IPA Menggunakan Model Pembelajaran Kooperatif Tipe STAD. Jurnal Tarbawi STAI Al Fithrah, 7(2). Retrieved from http://ejournal.kopertais4.or.id/susi/index.php/tarbawi/article/view/3022

Wulandari, N. S. dan F. E. (2018). Model Problem Based Learning (PBL) dalam Melatih Scientific Reasoning Siswa. Jurnal Penelitian Pendidikan IPA (JPPIPA), 4(3). https://doi.org/DOI: http://dx.doi.org/10.26740/jppipa.v3n1

Zain, S. B. D. dan A. (2014). Strategi Belajar Mengajar. Jakarta: Rineka Cipta. 